\section{IJ\$ER}

ISSN: 2149-5939
International Journal of Social Sciences and Education Research

Online, http://dergipark.gov.tr/ijsser

Volume: 3(2), 2017

\title{
Cebirsel sözel problemleri çözme stratejileri ve hatalarının analizi: Öğretmen boyutu
}

\author{
The analysis of algebraic word problem solving strategies and mistakes: \\ Teacher dimension
}

Ayten Pınar Bal1

Received Date: $01 / 09$ / 2016
Ahmet Karacaoğlu²

Accepted Date: 15 / $01 / 2017$

\begin{abstract}
$\ddot{O} z$
Bu araştırmanın amacı cebirsel sözel problemlerin çözümüne yönelik stratejilerin ve yapılan hata türlerinin öğretmen bakış açısıyla değerlendirilmektir. Nitel araştırma yöntemine göre tasarlanan bu çalışma Adana ili merkez ilçelerine bağlı okullarda görev yapan on iki matematik öğretmeni ile yürütülmüş̧ür. Araştırmada, veri toplama aracı olarak ögretmenler için hazırlanan yarı yapılandırılmış görüsme formu kullanılmıștır. Görüșe formunda, araştırmanın amaçlarına uygun olarak ögrencilerin cebirsel sözel problemleri çözmede uyguladıkları stratejiler, yapabilecekleri hatalar ve bu hataların giderilmesine yönelik düşüncelerini derinlemesine irdeleyen açık uçlu sorular bulunmaktadır. Araştırmanın sonucunda öğretmenlere göre öğrencilerin deneme yanılma, sistematik dağıtma, ters işlem, denklem kurma ve çözme stratejilerini etkili olarak uygulayabileceklerini düşündükleri ortaya çıkarılmıștır. Ayrıca çalışmanın sonucunda ögretmenlere göre ögrencilerin soruların çözümünde en çok mantık hatast yapabileceklerini düşündükleri ortaya konmuştur. Bu bağlamda öğretmenlerin sınıf içerisinde öğrencilerinin özellikle mantık hatalarını giderici yönde örnek sorulara ă̆ırlık vermeleri ve cebirsel akıl yürütme stratejilerini geliştirici yönde etkinlikler düzenlemeleri önerilebilir.
\end{abstract}

Anahtar sözcükler: Cebir, Problem çözme stratejisi, Matematik öğretmenleri.

\begin{abstract}
This research was aim to evaluate solution strategies of algebraic verbal problems and generated error types in terms of the point of views of teachers. This study is a study in which quantitative methods were used to obtain the point of views of teachers towards strategies and error types in solution of algebraic verbal problems. The primary school mathematics teachers working in schools of central counties of Adana province in 2012-2013 academic year formed the population of this research. In sum, in the scope of this study it was found out that the teachers think the students can apply trial and error, systemmatic distribution, inverse operation, forming and solving equation strategies effectively and they can mostly make logical mistakes. In this study only the opinions of teachers were taken. Studies in which the opinions of students are taken, will also be done. It can be suggested that the teachers can concentrate on questions in class that can resolve logical errors and use activities that can develop their algebraic reasoning strategies.
\end{abstract}

Keywords: Algebraic, Problem solving strategies, Mathematics teachers.

\section{Giriş}

Matematik, bireylerin kendi yaşantılarında ihtiyaç duyduğu bilgi ve becerileri kazanmalarını sağlamak, onların problem çözmeyi öğrenmelerine yardımcı olmak, ortaya çıkan sorunlar ve olaylar karşısında problem çözme yaklaşımı içinde düşünce üretme becerisi kazandırmaktır (NCTM, 2000). Günlük hayatta karşılaşılan problemlerin çözümünde farklı çözüm yollarının üre-

\footnotetext{
${ }^{1}$ Çukurova University, Adana, TURKEY, apinar@cu.edu.tr

${ }^{2}$ Milli Eğitim Bakanlığ akaracaoglu01@gmail.com
} 
Bal, A.P., Karacaoğlu, A. (2017). The analysis of algebraic word problem solving strategies and mistakes:

Teacher dimension. International Journal of Social Sciences and Education Research, 3(2), 448-455.

tilmesinde ise en çok cebirden yararlanılmaktadır. Genel olarak cebir, sayı ve semboller kullanarak eldeki incelenen ilişki veya ilişkileri genelleştirilmiş denklemlere dönüştüren bir matematik dalıdır. Cebir, öğrencilere soyut düşünmenin ve mantıksal çıkarım yapmanın kapılarını açar (Stacey ve MacGregor, 2000).

İlgili literatür incelendiğinde, cebirsel sözel problemlerin çözüm stratejileri ve yapılan hata türleri ile ilgili yürütülen çalışmaların genellikle öğrenci boyutu üzerine odaklandığı göze çarpmaktadır (Akkan, Baki ve Çakıroğlu, 2012; Baş, Erbaş ve Çetinkaya, 2011; Ergöz, 2000; Güner ve Alkan, 2011; Karataş ve Güven, 2003; Lee ve Chang, 2012; Sert, 2007; Soylu ve Soylu, 2006). Ancak öğretmen boyutunu derinlemesine irdeleyen sınırlı sayıda çalışmadan söz edilebilir (Baş, Erbaş ve Çetinkaya, 2011; Dede \& Peker, 2007). Bu kapsamda, Baş ve arkadaşları (2011) lise matematik öğretmenlerine göre öğrencilerinin cebirsel düşünme düzeyleri ile ilgili bilgi ve görüşlerini ortaya çıkarmayı amaçladıkları araştırmalarında, öğrencilerin çözüm yaklaşımları ile ilgili yanlış ya da eksik tahminlerde bulundukları sonucuna ulaşmışlardır.

Yukarıda ifade edilen bilgiler 1şığında, bu araştırma ile cebirsel sözel problemlerin çözümüne yönelik stratejilerin ve yapılan hata türlerinin öğretmen bakış açısıyla değerlendirilmesi amaçlanmıştır. Bu genel amaç doğrultusunda araştırmada aşağıda değinilen sorulara cevap aranmıştır:

1)Öğretmenlerin, cebirsel sözel problemlerin çözümüne yönelik uygulanan stratejilerle ilgili görüşleri nelerdir?

2)Öğretmenlerin, cebirsel sözel problemlerin çözümüne yönelik hata türleri hakkındaki görüşleri nelerdir?

3)Öğretmenlerin, cebirsel sözel problemlerin çözümünde yapılan hataların giderilmesine yönelik çözüm önerileri nelerdir?

\section{Yöntem}

Bu araştırma, cebirsel sözel problemlerin çözümüne yönelik stratejilerin ve yapılan hata türlerinin öğretmenlerin bakış açılarına göre belirlenmesi amacıyla yapılan nitel bir çalışmadır.

\section{1. Çalışma grubu}

Çalışma grubunu Adana ili merkez ilçelerine (Çukurova, Sarıçam, Seyhan ve Yüreğir) bağlı okullarda görev yapan on iki matematik öğretmeni oluşturmaktadır. Buna göre araştırmanın çalışma grubunu oluşturan öğretmenlerin sekizi kadın, dördü erkek olup, mesleki kıdemleri açısından gruplandığında ise, altısı 0-10yıl, dördü 11-20 yıl, ikisi ise 21-30 yıl kıdeme sahiptirler.

\subsection{Veri toplama aracı}

Araştırmada, veri toplama aracı olarak öğretmenler için hazırlanan yarı yapılandırılmış görüşme formu kullanılmıştır. Görüşme formunda, araştırmanın amaçlarına uygun olarak öğrencilerin cebirsel sözel problemleri çözmede uyguladıkları stratejiler, yapabilecekleri hatalar ve bu hataların giderilmesine yönelik düşüncelerini derinlemesine irdeleyen açık uçlu sorular bulunmaktadır. Soruların anlaşılabilirliğini ve uygulanabilirliğini test etmek amacıyla gönüllülük ilkesine bağlı kalarak iki öğretmenle pilot uygulama yapılarak forma son hali verilmiştir. Öğretmenler için geliştirilen yarı yapılandırılmış görüşme formu iki bölümden oluşmuştur. Birinci bölüm öğretmenlerin mesleki kıdemi, mezun olduğu okul ve hangi sınıf düzeyinde derse girdiklerine ilişkin üç sorudan oluşmaktadır. İkinci bölümde ise, Karacaoğlu (2015) tarafından geliştirilen Cebirsel 
Bal, A.P., Karacaoğlu, A. (2017). Cebirsel sözel problemleri çözme stratejileri ve hatalarının analizi: Öğretmen boyutu. International Journal of Social Sciences and Education Research, 3(2), 448-455.

Sözel Problemleri Çözme Stratejilerini ve Hatalarını Belirleme Testi (CSHT)'nden yararlanılmıştır. Yarı yapılandırılmış formda yer alan soruların yanı sıra, görüşme sırasında gerekli görüldükçe ek sorular da yöneltilmiştir.

\subsection{Verilerin analizi}

Verilerin analizinde betimsel ve içerik analizi uygulanmıştır. Betimsel analizde amaç elde edilen bulguları düzenlenmiş ve yorumlanmış bir biçimde okuyucuya sunmaktır (Yıldırım ve Şimşek, 1999). Bu çalışmada da bu analiz yardımıyla öğretmenlere göre öğrencilerin cebirsel sözel problemleri çözerken uygulayabilecekleri stratejilerin ve hataların neler olduğu literatürden yararlanılarak kodlanmıştır. Son alt amacın analizinde ise içerik analizi uygulanmıştır.

\section{Bulgular}

Araştırmanın birinci alt amacında öğretmenlere göre öğrencilerin sözel problemlerin çözümünde uyguladıkları stratejilere ilişkin görüssleri Tablo 1'de görülmektedir.

Tablo 1. Sözel problemlerin çözümünde öğrencilerin uyguladıkları stratejilere yönelik öğretmen görüşleri

\begin{tabular}{llll}
\hline \multicolumn{1}{c}{ Strateji } & f (6. sınıf) & f (7.sınıf) & f (8.sınıf) \\
\hline Ters İşlem & 25 & 10 & 13 \\
Deneme-Yanılma & 16 & 11 & 9 \\
Sistematik Dağıtma & 12 & 1 & \\
Orantısal Akıl Yürütme & 11 & 5 & 2 \\
Bölme Sonrası Düzenleme & 7 & 1 & 1 \\
Uzunluk Ve Dikdörtgen Boyutu Çizme & 2 & 2 & 2 \\
Denklem Kurma Ve Çözme & 1 & 46 & 54 \\
\hline
\end{tabular}

Tablo 1'de görüldüğü gibi, 6. Sınıf öğrencileri için öğretmenlerin görüşme verileri incelendiğinde öğretmenlerin büyük çoğunluğu ters işlem (25), deneme yanılma (16) ile sistematik dağıtma (12) stratejilerinin uygulanabileceğini düşündüklerini belirtmişlerdir. Bu kapsamda Ö5 kodlu öğretmen 5. sorunun çözüm stratejisi için düşüncesini "çevreyi ikiye bölerek uzun kenar ile kısa kenar toplamını bulur. Bulunan sonuçtan fazlalık olan 3 'ü çıkarır. Kalan sonucu ikiye bölerek kısa kenar uzunluğunu, ardından üç ekleyerek de uzun kenar uzunluğunu bulur" şeklinde ifade etmiştir. Diğer taraftan ters işlem stratejisinin uygulanabileceğini ifade eden Ö2 kodlu öğretmen 1. sorunun çözümü için görüşünü “ At saylsından ilerleyerek koyun ve inek sayısına ulaşabilirler. Yani sondan başa doğru bir yol izleyebilirler" şeklinde ifade etmiştir. Diğer taraftan öğrencilerin denklem kurma ve çözme stratejilerini kullanabilecekleri yönünde görüşlerini dile getiren altınc1 sınıf öğretmenlerinden birinin görüşü ise şöyledir: “ Hayvanlardan birini baz alarak diğerlerinin ona göre cebirsel karşılığını bulup soruyu çözmeye çalışırlar. At sayısı bilindiğinden bundan hareket ederler" (Ö4, birinci soru).

Öte yandan, yedinci sınıf öğrencileri için öğretmenler en çok denklem kurma ve çözme (46), deneme yanılma (11), ters işlem (10) stratejilerini etkili olarak kullanabileceklerini ifade etmişlerdir. Bu yönde bazı öğretmenlerin görüşleri şöyledir: "Burcu'nun yaşını a ve annesinin yaşını a+24 olarak alıp bunların toplamını 48'e eşitleyerek denklem kurarlar ve denklemi çözümünde Burcu ve annesinin yaşını ayrı ayrı bulurlar" (Ö12), "Soru kısmından harekete başlayarak 
Bal, A.P., Karacaoğlu, A. (2017). The analysis of algebraic word problem solving strategies and mistakes:

Teacher dimension. International Journal of Social Sciences and Education Research, 3(2), 448-455.

bulana kadar denerler" (Ö6) ve "sonuçtan başlayıp işlemlerin tersini yaparak istenileni bulmaya çalışırlar" (Ö3).

Son olarak sekizinci sınıf öğrencileri için öğretmenler denklem kurma ve çözme (54), ters işlem (13) ve deneme yanılma (9) stratejilerini etkili olarak uygulayabileceklerini düşündüklerini söylemişlerdir. Örneğin Ö11 kodlu öğretmen " Sondan başlayarak yapacakttr. Tuttuğu sayıya $x$ demez. Kolay olanı seçecektir" şeklinde görüşünü ifade ederken Ö1 kodlu öğretmen ise “Ali'nin tuttuğu saylya $x$ der ve $(7 x-4) / 2=12$ denklemini çözerek bulur" şeklinde görüşünü belirtmiştir.

Araştırmanın ikinci alt amacına göre öğretmenlerin öğrencilerin cebirsel sözel problemleri çözerken yaptıkları hatalarla ilgili görüşleri Tablo 2'de yer almaktadır.

Tablo 2. Öğretmenlerin öğrencilerin cebirsel sözel problemleri çözerken yaptıkları hatalarla ilgili görüşleri

\begin{tabular}{lllll}
\hline Hatalar & f (6. sınıf) & f (7. sınıf ) & f (8. sinıf ) & Toplam \\
\hline Mantık Hatası & 58 & 38 & 31 & 127 \\
İslem Hatası & 14 & 15 & 24 & 53 \\
Denklem Kurma Hatası & 6 & 21 & 24 & 51 \\
Eksik Çözüm & 7 & 5 & 7 & 19 \\
\hline
\end{tabular}

Tablo 2'de görüldüğü gibi öğretmenler, tüm sınıf düzeylerindeki öğrencilerin soruların çözümünde en çok mantık hatası (127) yapabileceklerini belirtmişlerdir. Öğrencilerin mantık hatası yapabileceklerini ifade eden öğretmenlerden bir kaçının görüşü şöyledir : “At saylsına dikkat etmeden hayvan sayısından yola çıkarak çözümü daha karmaşık hale getirebilirler” (Ö2); “...soruyu tam olarak okumayıp verilenleri ve istenenleri anlamadan çözüme geçebilirler" (Ö3).

Son alt amaç olarak öğrencilerin cebirsel sözel problemlerin çözümünde yapabilecekleri hataların giderilmesine yönelik öğretmenlerin çözüm önerilerinin neler olabileceği konusunda ki görüşleri Tablo 3'te yer almaktadır.

Tablo 3. Cebirsel sözel problemlerin çözümünde öğrencilerin yapabilecekleri hataların giderilmesine yönelik öğretmenlerin çözüm önerilerine ilişkin görüşleri

\begin{tabular}{llr}
\hline Tema & Kodlar & f \\
\hline & Konuyla ilgili çok sayıda örnek çözülmeli & 4 \\
& Soruların çözümünde görselleştirilme yoluna gidilmeli & 3 \\
& Konunun mantığı kavratılmalı & 3 \\
& Konu farklı yöntemlerle anlatılmalı & 2 \\
Öğretmenlere Yönelik & Öğrencilere bilinmeyeni ayırt edebilecek ön çalışmalar yaptırılmalı & 1 \\
Öneriler & Soyuttan somuta geçilmesi sırasında yaşanan sorunların giderilmesine & 1 \\
& yönelik çalışmalar yapılmalı & 1 \\
& Bol kitap okumalarını sağlayarak sözel problemlerin daha iyi anlamala- & 1 \\
& rına yardımcı olunmalı & 1 \\
& Konuyla ilgili yorum yapmalarına imkân verilmeli & 1 \\
\hline & Sorunun çözümüyle ilgili ipucu verilmeli & 4 \\
Öğrencilere Yönelik & Problemi iyi anlamalı & 4 \\
Öneriler & Öğrenci neye “x” denilmesi gerektiğini fark edebilmeli & 3 \\
& Cebirsel ifade yazmayı iyi bilmeli & 1
\end{tabular}


Bal, A.P., Karacaoğlu, A. (2017). Cebirsel sözel problemleri çözme stratejileri ve hatalarının analizi: Öğretmen boyutu. International Journal of Social Sciences and Education Research, 3(2), 448-455.

Tablo 3 incelendiğinde öğretmenlerin görüşleri öğretmenlere yönelik öneriler ve öğrencilere yönelik öneriler olmak üzere iki tema altında toplanmaktadır. İlk temada öğretmenler en çok konuyla ilgili çok sayıda örnek çözülmesi gerektiğini (4), soruların çözümünde görselleştirilme yoluna gidilmesini (3) ve konunun mantığının kavratılması (3) gerektiğini belirtmişlerdir. Bu yönde görüş belirten öğretmenlerden bir kaçının düşüncesi şu şekildedir: “ Öğrencilere kavramlar detaylı olarak verilmeli ve çok sayıda pratik yaptırılmalıdır. Değişken ve bilinmeyen kavramları yeterince tanıtılmalı ve bol bol denklem çözdürülmelidir. Problem çözümünde örnek çeşitliliği olabildiğince arttırılmalıdır” (Ö4); “Bazı sorularda şekil çizilerek öğrencinin denklem kurmasına kolaylık sağlanabilir” (Ö5); “ Problemin çözümünde problem önce iyice anlatılmalı ve gerekirse şekil çizilmelidir. Pekiştirmek için çok sayıda örnek verilmelidir”(Ö1); “Soru çözümleri yapılırken görsel öğelere daha fazla yer verilmesi, şekillerin daha fazla kullanılması ezber yapmaktan çok konunun mantı̆̆ını anlamaya yardımcı olacaktır" (Ö10).

Diğer temada ise öğrencilere yönelik önerilerde bulunan öğretmenlerden dördü problemin iyi anlaşılması gerektiğini, diğer dördü öğrencinin neye "x" denilmesi gerektiğini fark edebilmesi gerektiğini, üçü cebirsel ifadeyi yazmayı iyi bilmesi gerektiğini ve biri de öğrencilerin hazır bulunuşluk düzeylerinin tam olması gerektiğini belirtmişlerdir. Örneğin Ö2 kodlu öğretmen bu yöndeki düşüncesini “ Denklem çözümü ya da harfli ifadeyi yazma konusunda ögrrencilerin dikkatle çözüme ulaşmaları gerekiyor. Bu konuda 6. sinıftaki eksik ögrrenme sorun yaratacaktır” şeklinde belirtirken Ö11 kodlu öğretmen ise “ Öğrencilerin hazır bulunuşluğuna göre ögrretim yapılmalı. Cebirsel ifadeler konusunda x'in hangi anlamda kullanıldlğg ögrretilmeli ve böylelikle ögrrenci neye $x$ diyeceğini bilmelidir" şeklinde düşüncesini ifade etmiştir.

\section{Sonuç ve öneriler}

Cebirsel sözel problemlerin çözümüne yönelik stratejilerin ve yapılan hata türlerinin öğretmenlerin bakış açılarına göre belirlenmesi amacıyla yapılan bu araştırmanın sonucunda öğretmenlere göre öğrencilerin deneme yanılma, sistematik dağıtma, ters işlem, denklem kurma ve çözme stratejilerini etkili olarak uygulayabileceklerini düşündükleri ortaya çıkarılmıştır. Bu sonuç ilgili literatür ile desteklenmektedir. Bu bağlamda, Karataş ve Güven (2003) sekizinci sınıf öğrencileriyle yaptığı nitel araştırmada öğrencilerin denklem kurmada ve sonuca ulaşmada zorluk yaşadıklarını ortaya çıkarmışlardır. Van Dooren, Verschaffel \& Onghena, (2002) ise öğretmen adaylarıyla yaptıkları çalışmada, hem ortaokul öğretmen adaylarının hem de öğrencilerin cevaplarının değerlendirilmesinde en çok cebirsel stratejilere başvurulduğu; ilkokul öğretmen adaylarının ve öğrencilerinin ise en çok aritmetiksel stratejilere başvurdukları bulgusuna ulaşmışlardır. Diğer taraftan öğretmenlere göre öğrencilerin soruların çözümünde en çok mantık hatası yapabileceklerini düşündükleri de araştırmadan elde edilen diğer önemli bir sonuçtur.

$\mathrm{Bu}$ çalışma sonuçları sadece öğretmen görüşleri alınarak yapılmıştır. Bu konuda öğrencilerin de görüşlerini kapsayan araştırmalar da yapılabilir. Öğretmenlerin sınıf içerisinde öğrencilerinin özellikle mantık hatalarını giderici yönde örnek sorulara ağırlık vermeleri ve cebirsel akıl yürütme stratejilerini geliştirici yönde etkinlikler düzenlemeleri önerilebilir. 
Bal, A.P., Karacaoğlu, A. (2017). The analysis of algebraic word problem solving strategies and mistakes:

Teacher dimension. International Journal of Social Sciences and Education Research, 3(2), 448-455.

\section{Kaynakça}

Baş, S., Erbaş, A. K. ve Çetinkaya, B. (2011). Öğretmenlerin dokuzuncu sınıf öğrencilerinin cebirsel düşünme yapılarıyla ilgili görüşleri. Eğitim ve Bilim, 36(59), 41-55.

Dede, Y. \& Peker, M. (2007). Öğrencilerin cebire yönelik hata ve yanlış anlamaları: matematik öğretmen adayları'nın bunları tahmin becerileri ve çözüm önerileri. İlköğretim Online, 6(1), 35-49.

Ergöz, N. (2000). Aritmetikten Cebire Kademeli Geçişi Vurgulayan Eğitimin Etkileri, Yayınlanmamış Yüksek Lisans Tezi, Boğaziçi Üniversitesi Fen Bilimleri Enstitüsü, İstanbul.

Güner, N. \& Alkan, V. (2011). İlköğretim ve Ortaöğretim öğrencilerinin 2010 YGS matematik sorularını cevaplandırırken yaptıkları hatalar. Pamukkale Üniversitesi Eğitim Fakültesi Dergisi Sayı 30, . 125140.

Karataş, İ. \& Güven, B. (2003). Problem çözme davranışlarının değerlendirilmesinde kullanılan yöntemler: Klinik mülakatın potansiyeli. İlköğretim-Online, 2(2), .2 - 9. MEB. http://oks2007.meb.gov.tr (16.07.2007).

Lee, H. \& Chang, K. (2012). Elementary student's algebraic reasoning abilities in mathematics problem solving, 12th International Congress on Mathematical Education, July 8-15, COEX, Seoul, Korea.

NCTM. (2000). Principles and standards for school mathematics, Reston, VA: National Council of Teachers of Mathematics.

Sert, Ö. (2007). Eight grade students' skills in translating among different representations of algebraic concepts. Yüksek lisans tezi, Ortadoğu Teknik Üniversitesi, Sosyal Bilimler Enstitüsü, Ankara.

Soylu, Y. \& Soylu, C. (2006). Matematik derslerinde başarıya giden yolda problem çözmenin rolü, İnönü Üniversitesi Eğitim Fakültesi Dergisi.

Stacey, K. \& MacGregor, M. (2000). Learning the algebraic method of solving problems, Journal o Mathematical Behavir, S.18 . 149-167.

Van Dooren, W, Verschaffel, L. \& Onghena, Patrick. (2002). The impact of preservice teachers' content knowledge on their evaluation of students' strategies for solving arithmetic and algebra word problems. Journal for Research in Mathematics Education. Vol. 33, No. 5, 319-351.

Yıldırım, A. \& Şimşek, H. (1999). Sosyal bilimlerde nitel araştırma yöntemleri, Ankara: Seçkin Yayıncılık.

\section{Extended abstract in English}

Mathematics is one of the most important means that is known to change and develop the thinking way of people. In this scope, maths education forms one of the important, may be the most important components of primary education (Umay, 2003). In literature it is observed that most of the studies addressing solution strategies of algebraic verbal problems and generated error types were done with students (Akkan, 2011). In this scope, it is thought that the findings obtained from this study and suggestions done in the direction of these findings are important in terms of maths teachers and programme development specialists.

Based on the facts mentioned above, with this research it was aimed to evaluate solution strategies of algebraic verbal problems and generated error types in terms of the point of views of teachers. Based upon this general aim, the answers of the questions mentioned below were searched:

1) What are the opinions of teachers regarding strategies used towards the solution of algebraic verbal problems? 
Bal, A.P., Karacaoğlu, A. (2017). Cebirsel sözel problemleri çözme stratejileri ve hatalarının analizi: Öğretmen boyutu. International Journal of Social Sciences and Education Research, 3(2), 448-455.

2) What are the opinions of teachers regarding error types towards the solution of algebraic verbal problems?

3) What are the opinions of teachers regarding resolution of error types done in the solution of algebraic verbal problems?

This study is a study in which quantitative methods were used to obtain the point of views of teachers towards strategies and error types in solution of algebraic verbal problems. The primary school maths teachers working in schools of central counties of Adana province in 2012-2013 academic year formed the population of this research. In determining studying group of this research, the teachers were interviewed according to criterion sampling method from purposeful sampling methods. As criterion, the volunteer teachers that are experienced at least six years and working with sixth, seventh and eighth graders were chosen. 8 of the teachers that formed study group are women whereas 4 of them are men. As grouped in terms of professional seniority six of them have 6-10 years, four of them have 11-20 years and two of them have 21-30 years. In semi-structured question form that was formed for teachers, open ended semi structured interview form was prepared to adress opinions comprehensively regarding strategies applied in solving algebraic verbal problems, possible errors and resolution of these problems by students.

In analysis of datas descriptive and content analysis were used. In this study the opinions of teachers were collected under specific themes and codes regarding the solution suggestions of teachers towards resolution of errors in solving of algebraic verbal problems.

It was found out that the teachers think the students can apply trial and error, systemmatic distribution, inverse operation, forming and solving equation strategies effectively. This result is also supported by related literature. Karataş and Güven (2003) presented that students have difficulty in forming equation and reaching solution in their quantitative study done with eighth grade students.

In the study done to find out opinions of high school maths teachers and students regarding algebraic thinking ways and how this data reflect the thinking ways of students to what extend (Baş, Erbaş \& Çetinkaya, 2011), firstly algebraic thinking structure of students on a generalisation was found then the knowledge and expectations of teachers on this generalisation was researched, the difference between the real performance and ideas of teachers about students was observed however when solution papers were examined systemmatically, it was found out that teachers could interpret the thinking ways of students better.

In the study done with primary and secondary school teacher candidates, Van Dooren and his colleagues (2002) examined the answers given by teachers to the test applied at the beginning and at the end of teacher training and evalution of teachers of answers given by students. It was seen that as secondary school teacher candidates preferred algebraic strategies in evalution of answers of both theirs and students, primary school teacher candidates used arithmetical strategies and made numerical errors in solutions. It can be said that those findings show similarity with the findings of research.

On the other hand, it was found out that teachers think that students can mostly make logical mistakes in solving of questions. Since there is not any source that shows similarity or difference in literature any comparison cannot be done. The teachers just mentined their opinions for this sub aim. 
Bal, A.P., Karacaoğlu, A. (2017). The analysis of algebraic word problem solving strategies and mistakes:

Teacher dimension. International Journal of Social Sciences and Education Research, 3(2), 448-455.

In sum, in the scope of this study it was found out that the teachers think the students can apply trial and error, systemmatic distribution, inverse operation, forming and solving equation strategies effectively and they can mostly make logical mistakes. In this study only the opinions of teachers were taken. Studies in which the opinions of students are taken, will also be done. It can be suggested that the teachers can concentrate on questions in class that can resolve logical errors and use activities that can develop their algebraic reasoning strategies. 